\title{
Critical Dependence of cAMP Response Element-Binding Protein Phosphorylation on L-Type Calcium Channels Supports a Selective Response to EPSPs in Preference to Action Potentials
}

\author{
Paul G. Mermelstein, Haruhiko Bito, Karl Deisseroth, and Richard W. Tsien \\ Department of Molecular and Cellular Physiology, Stanford University School of Medicine, Stanford, California 94305
}

Activity-dependent gene expression in neurons shows a remarkable ability to differentiate between different types of stimulation: orthodromic inputs that engage synaptic transmission are much more effective than antidromic stimuli that do not. We have studied the basis of such selectivity in cultured hippocampal neurons in which nuclear cAMP response element-binding protein (CREB) phosphorylation is induced by synaptic activity but not by action potential (AP) stimulation in the absence of EPSPs, although spikes by themselves generate large elevations in intracellular $\mathrm{Ca}^{2+}$. Previous work has shown that $\mathrm{Ca}^{2+}$ entry through L-type $\mathrm{Ca}^{2+}$ channels plays a dominant role in triggering calmodulin mobilization and activation of calmodulindependent kinases that phosphorylate CREB, raising the possibility that L-type channels contribute to the selective response to EPSPs rather than APs. Accordingly, we performed voltage-clamp experiments to compare the currents carried by L-type channels during depolarizing waveforms that approxi- mated APs or dendritic EPSPs. The integrated current generated by L-type channels was significantly less after mock APs than with EPSP-like depolarizations. The difference was traced to two distinct factors. Compared with other channels, L-type channels activated at relatively negative potentials, favoring their opening with EPSP stimulation; they also exhibited relatively slow activation kinetics, weighing against their contribution during an AP. The relative ineffectiveness of APs as a stimulus for CREB phosphorylation could be overcome by exposure to the agonist Bay K8644, which potentiated the AP-induced influx through L-type channels by $\sim 10$-fold. Under normal conditions, the unique biophysical properties of L-type channels allow them to act as a kinetic filter to support spike-EPSP discrimination.

Key words: calmodulin; CREB; hippocampus; calcium channels; gene expression; dihydropyridine; NMDA; Bay K8644
Activity-dependent regulation of gene expression is essential for long-term changes in neuronal structure and function (Kandel et al., 1986; Ghosh et al., 1994; Bito et al., 1996; Impey et al., 1998). As a general rule, neurons are capable of responding selectively to certain kinds of activity and not to others. One of the most fundamental forms of such selectivity is the ability to discriminate between EPSPs and spike firing, despite the fact that both forms of activity strongly raise bulk intracellular $\mathrm{Ca}^{2+}$ concentrations (Deisseroth et al., 1996). Stimulation by EPSPs and action potentials (APs) each represent physiological stimuli: EPSPs are generated by synaptic transmission, whereas dendritic APs arise from back propagation of spikes originating within the cell body. There are several examples of neurons discriminating between APs and EPSPs. For example, synaptic stimulation of sympathetic neurons of the superior cervical ganglion causes increased levels of tyrosine hydroxylase, whereas antidromic stimulation produced no change (Chalazonitis and Zigmond, 1980). Likewise, c-fos expression in magnocellular neurons of the hypothalamus rises in re-

\footnotetext{
Received Aug. 25, 1999; revised Oct. 18, 1999; accepted Oct. 20, 1999.

This work was supported by National Institutes of Health Grants MH48108 and GM58234 to R.W.T., a SmithKline Beecham postdoctoral fellowship to P.G.M., a long-term fellowship from the Human Frontiers Science program to H.B., and a Medical Scientist Training Program fellowship to K.D. We thank Drs. G. S. Pitt, E. S. Piedras-Renteria, E. Kavalali, S. M. Smith, C. Harata, and J. Klingauf for their thoughtful comments, and Dr. D. B. Wheeler for help with the figures.

Correspondence should be addressed to Richard W. Tsien, Department of Molecular and Cellular Physiology, Stanford University School of Medicine, Stanford, CA 94305. E-mail: rwtsien@leland.stanford.edu.

Dr. Bito's present address: Department of Pharmacology, Kyoto University School of Medicine, Kyoto 606-8315, Japan.

Copyright (C) 1999 Society for Neuroscience $\quad 0270-6474 / 99 / 200266-08 \$ 15.00 / 0$
}

sponse to orthodromic but not antidromic stimulation (Luckman et al., 1994). The same kind of disparity occurs in hippocampal neurons in which phosphorylation of cAMP response elementbinding protein (CREB) at $\operatorname{Ser}^{133}$ occurs with EPSPs but not spike stimulation (Bito et al., 1996; Deisseroth et al., 1996).

This study was undertaken to clarify the basis of the sharply contrasting responses after synaptic activity-based depolarizations as opposed to the generation of action potentials in the absence of intercellular neurotransmission. To do so, we monitored CREB phosphorylation in dissociated cell cultures derived from rat hippocampi by means of an antibody to phospho-Ser ${ }^{133}$ (Ginty et al., 1993). Under these conditions, CREB signaling occurs after activation of either L-type voltage-gated $\mathrm{Ca}^{2+}$ channels or NMDA receptors (NMDARs) (Sheng et al., 1991; Deisseroth et al., 1996). These sources of $\mathrm{Ca}^{2+}$ entry are tightly linked to $\mathrm{CaM}$ translocation and nuclear signaling to the near exclusion of other $\mathrm{Ca}^{2+}$ influx pathways (Deisseroth et al., 1998). NMDARs contribute to EPSP-spike discrimination because NMDAR-mediated CREB phosphorylation is clearly dependent on the release of synaptic glutamate. Whether and how voltagegated, L-type $\mathrm{Ca}^{2+}$ channels can discriminate between spike and EPSP depolarizations is currently unknown. In an attempt to uncover the means by which L-type channels help discriminate between these different types of stimuli, their biophysical properties were closely examined.

\section{MATERIALS AND METHODS}

Cell culture. Pyramidal CA3-CA1 hippocampal neurons were cultured as described previously (Malgaroli and Tsien, 1992). Briefly, 2-d-old rat 
pups were decapitated, and their brains quickly isolated and then placed into an ice-cold, modified HBSS (H-2387; Sigma, St. Louis, MO) containing: $4.2 \mathrm{~mm} \mathrm{NaHCO}$ and $1 \mathrm{~mm}$ HEPES with $20 \%$ fetal bovine serum (FBS) (Hyclone, Logan, UT), pH 7.35, 300 mOsm. After isolation of the hippocampi, the dentate gyri were discarded, and the remaining tissue was cut into five to six pieces. The tissue was combined in a $15 \mathrm{ml}$ centrifuge tube (Corning, Corning, NY), washed three times with HBSS containing $20 \%$ FBS, and then three times with HBSS alone. The tissue was then enzymatically digested for $5 \mathrm{~min}$ with $10 \mathrm{mg} / \mathrm{ml}$ trypsin (type $\mathrm{XI}$; Sigma) in a solution that contained (in $\mathrm{mm}$ ): $137 \mathrm{NaCl}, 5 \mathrm{KCl}, 7$ $\mathrm{Na}_{2} \mathrm{HPO}_{4}$, and $25 \mathrm{HEPES}, \mathrm{pH} 7.2,300$ mOsm. Afterwards, the tissue was washed twice with HBSS containing $20 \%$ FBS and three times with HBSS alone. The cells were dispersed using a series of Pasteur pipettes with decreasing diameter in $2 \mathrm{ml}$ of HBSS containing: $12 \mathrm{mM} \mathrm{MgSO}_{4}$ with $20 \%$ FBS, pH 7.35, 310 mOsm. After dispersion, 3 ml of HBSS with $20 \%$ FBS was added to the centrifuge tube. The cells were then spun at 1000 $\mathrm{rpm}$ for $10 \mathrm{~min}$ at $4^{\circ} \mathrm{C}$. After the supernatant was aspirated, the cells were resuspended in $2 \mathrm{ml}$ of HBSS plus $3 \mathrm{ml}$ of HBSS with 20\% FBS and spun once more. The supernatant was again discarded, and the cells were resuspended in HBSS containing 20\% FBS. The cells were then plated onto $1 \mathrm{~cm}$ coverslips. The cells were grown in $2 \mathrm{ml}$ of Minimum Essential Medium (MEM) (Life Technologies, Grand Island, NY) containing: 28 mm glucose, $2.4 \mathrm{~mm} \mathrm{NaHCO}, 0.0013 \mathrm{~mm}$ transferrin, $2 \mathrm{~mm}$ glutamine, $0.0042 \mathrm{~mm}$ insulin, and 10\% FBS, pH 7.35, $300 \mathrm{mOsm}$. All reagents were obtained from Sigma except transferrin (Calbiochem, La Jolla, CA). Twenty-four hours after plating, one-half of the MEM solution was replaced with a similar solution containing $4 \mu \mathrm{M} \mathrm{AraC}$ and 5\% FBS. Three days later, one-half of the solution was again replaced with plating media containing $5 \%$ FBS.

Acute dissociation. Three-week-old rat pups were decapitated, and their brains were quickly removed. Hippocampi were isolated using methods similar to those used for cell culture. Each hippocampus was cut into five to six pieces, followed by a $5 \mathrm{~min}$ exposure to $2 \mathrm{mg} / \mathrm{ml}$ protease (type XIV; Sigma) dissolved in an oxygenated, $37^{\circ} \mathrm{C}$ PIPES solution (in mM): $120 \mathrm{NaCl}, 5 \mathrm{KCl}, 1 \mathrm{CaCl}_{2}, 1 \mathrm{MgCl}_{2}, 20$ PIPES, and 25 glucose, $\mathrm{pH}$ 7.0, $300 \mathrm{mOsm}$. Afterwards, the tissue was transferred to an oxygenated chamber containing PIPES solution at room temperature until dissociation. When needed, cells were dispersed using a series of Pasteur pipettes and allowed to settle at the bottom of the recording chamber for at least 10 min before recording.

Electrophysiology. Whole-cell recordings of currents supported by somatic and proximal dendritic $\mathrm{Ca}^{2+}$ channels were performed using standard techniques (Hamill et al., 1981; Mermelstein et al., 1996). Warner GC120T-10 borosilicate glass electrodes (Warner Instrument Corp., Hamden, CT) were pulled on a Flaming/Brown P-87 puller (Sutter Instrument Co., Novato, CA) and fire polished with an MF-9 microforge (Narishige, Hempstead, NY). The intracellular recording solution contained (in mM): $190 \mathrm{~N}$-methyl-D-glucamine, $40 \mathrm{HEPES}, 5$ BAPTA, $4 \mathrm{MgCl}_{2}, 12$ phosphocreatine, $3 \mathrm{Na}_{2} \mathrm{ATP}$, and $0.2 \mathrm{Na}_{3} \mathrm{GTP}, \mathrm{pH}$ 7.2, $275 \mathrm{mOsm}$. The external recording solution contained (in $\mathrm{mM}$ ): 135 $\mathrm{NaCl}, 20 \mathrm{CsCl}, 1 \mathrm{MgCl}_{2}, 10 \mathrm{HEPES}, 0.001 \mathrm{TTX}$, and $5 \mathrm{BaCl}_{2}$. Because $\mathrm{Ca}^{2+}$ itself can have effects either directly or indirectly on voltagedependent $\mathrm{Ca}^{2+}$ channels, $5 \mathrm{mM} \mathrm{Ca}^{2+}$ was also used as the charge carrier. Replacing $\mathrm{Ba}^{2+}$ with $\mathrm{Ca}^{2+}$ shifted the voltage-dependence of activation and activation kinetics to more depolarized potentials by $\sim 10$ $\mathrm{mV}$. Reduction of the external $\mathrm{Ca}^{2+}$ concentration to physiological concentrations $(\sim 2 \mathrm{~mm})$ largely negates that shift. With either external $\mathrm{Ca}^{2+}$ or $\mathrm{Ba}^{2+}$, L-type channels activated at more negative potentials and did not fully activate with AP waveforms; apparently switching between charge carriers had no significant impact on the interpretation of our results (see Results). Nifedipine and $S(-)$-Bay K8644 were dissolved in ethanol as a $1000 \times$ stock $(5 \mathrm{~mm})$. All reagents were obtained from Sigma except ATP and GTP (Boehringer Mannheim, Indianapolis, IN), BAPTA (Calbiochem), nifedipine, and Bay K8644 (Research Biochemicals, Natick, MA). Extracellular recording solutions were applied with a gravity-fed Warner Instruments MP-8 manifold positioned several hundred microns away from the cell being recorded. The bath solution contained (in mM): $129 \mathrm{NaCl}, 5 \mathrm{KCl}, 30$ glucose, $25 \mathrm{HEPES}, 2 \mathrm{CaCl}_{2}, 1$ $\mathrm{MgCl}_{2}$, and 0.01 glycine. Current traces generated with mock AP waveforms were $\mathrm{Cd}^{2+}$ subtracted $(200 \mu \mathrm{M})$ to eliminate the capacitative artifact.

Recordings of acutely isolated or cultured hippocampal pyramidal neurons [5-6 d in vitro (d.i.v.)] were obtained with a patch-clamp L/M EPC 7 amplifier (ALA Scientific Instruments Inc., Westbury, NY) or an Axopatch 200A amplifier (Axon Instruments, Foster City, CA) con- trolled by a personal computer running pCLAMP (version 6.0) with a $125 \mathrm{kHz}$ interface (Axon Instruments). Electrode resistances were $\sim 4-6$ $\mathrm{M} \Omega$ in the bath. After a stable seal was obtained and the membrane patch under the electrode was ruptured, the series resistance was compensated by $>50 \%$ for cultured neurons and $>75 \%$ for acutely dissociated cells. Low-voltage-activated, T-type channels were not typically observed in either neuronal preparation. Recordings were performed at room temperature $\left(23^{\circ} \mathrm{C}\right)$. The junction potential $(<2 \mathrm{mV})$ was not compensated. Data were analyzed on a Power Macintosh workstation (Apple Computers, Cupertino, CA) using Axograph (version 3.5; Axon Instruments) software.

CREB immunocytochemistry. For field stimulation experiments, neurons $(8-12$ d.i.v.) were preincubated $2-4 \mathrm{hr}$ at room temperature in a Tyrode's solution containing (in mM): $129 \mathrm{NaCl}, 5 \mathrm{KCl}, 2 \mathrm{CaCl}_{2}, 1$ $\mathrm{MgCl}_{2}, 30$ glucose, 25 HEPES, 0.1 glycine, and 0.001 TTX. The recording chamber was perfused with the Tyrode's solution (no TTX) in the presence or absence of $5 \mu \mathrm{M}$ Bay K8644. Field stimuli (1 msec constant current pulses of $5 \mathrm{~mA}$ ) were applied for $18 \mathrm{sec}$ at $50 \mathrm{~Hz}$ or $180 \mathrm{sec}$ at 5 $\mathrm{Hz}$ by an Iso-Flex stimulus isolator (A.M.P.I., Jerusalem, Israel) in the presence of AP-5 $(25 \mu \mathrm{M})$ and CNQX $(10 \mu \mathrm{M})$ to eliminate synaptically driven EPSPs. After stimulation, cells were fixed for $\sim 30$ min with $10 \%$ paraformaldehyde (Electron Microscopy Sciences, Washington, PA) in PBS containing 4 mM EGTA. Coverslips were washed twice with PBS containing $100 \mu \mathrm{M}$ glycine and then permeabilized for $1-2 \mathrm{hr}$ in block solution [PBS with 4\% goat serum (Jackson ImmunoResearch, West Grove, PA) containing $0.4 \%$ saponin (Sigma)]. The cells were then incubated overnight in block solution containing a 1:1000 dilution of the anti-pCREB polyclonal antibody (Upstate Biotechnology, Lake Placid, NY). The next day, cells were washed three times in PBS plus $100 \mu \mathrm{M}$ glycine. After wash, cells were incubated 1-2 hr in the block solution containing the Texas Red-conjugated secondary antibody (1:200 dilution). Cells were washed five times with PBS and $100 \mu \mathrm{M}$ glycine and then covered with the anti-quenching reagent Citifluor (Citifluor UK Chemical Lab., Canterbury, UK). After the immunocytochemistry procedure, nuclear fluorescence measurements were performed using a Zeiss Axioplan inverted microscope (Zeiss, Thornwood, NY) containing standard epifluorescence attachments.

Induction of EPSPs was performed by stimulating one neuron in a region of several cells to maximize the probability of synaptic contacts (Deisseroth et al., 1996). It should be noted that, under these culture conditions, neurons do not form autapses. The target neuron was stimulated to generate action potentials with a bipolar electrode made from theta glass (Clark Electromedical Instruments, Pangbourne, UK). The stimulating electrode was filled with Neurobiotin (Vector Laboratories, Burlingame, CA) to allow staining with a 1:100 dilution of Cascade blue-conjugated avidin (Molecular Probes, Eugene, OR). As in the field stimulation experiments, cultured neurons were preincubated for 2-4 hr in Tyrode's containing TTX to minimize CREB phosphorylation induced by spontaneous electrical activity. After stimulation, cells were processed for immunocytochemistry as described above.

Statistics. Statistics were performed on a Power Macintosh workstation using either StatView (version 4.01; Abacus Concepts, Inc., Berkeley CA) or Systat (version 5.2 Systat Inc., Evanston, IL). Within-subjects $t$ tests or a repeated-measures ANOVA with $p<0.05$ were considered to be significant $a$ priori. Permeability estimates were determined using Axograph and KaleidaGraph software (version 3.0.4; Synergy Software, Reading, PA) as described previously (Bargas et al., 1994).

\section{RESULTS \\ CREB phosphorylation occurs with EPSP but not AP stimulation}

The differential impact of APs and synaptic EPSPs in cultured CA1-CA3 hippocampal pyramidal neurons has been described previously (Deisseroth et al., 1996) and is further documented here. Figure $1 A$ shows $5 \mathrm{~Hz}$ intracellular stimulation of an individual pyramidal neuron to produce APs in this "presynaptic" neuron and EPSPs but not APs in the surrounding "postsynaptic" cells. At this stage in culture, one-to-one synaptic connections are not powerful enough to fire action potentials given the presence of comparatively weak synapses and the temporal separation between individual EPSPs at moderate stimulation frequency, as verified by direct recordings from follower cells (Deisseroth et al., 

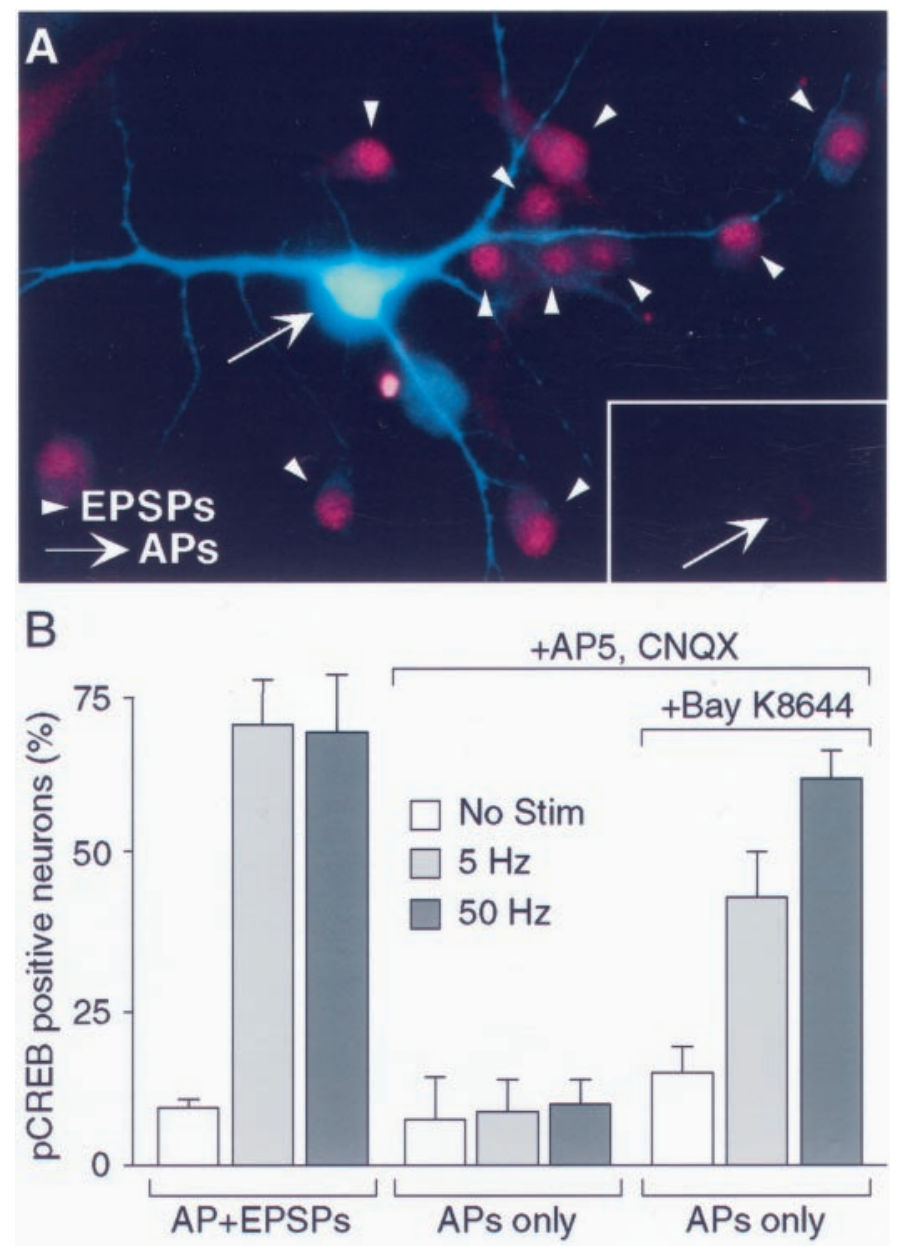

Figure 1. EPSPs, but not APs, are sufficient stimuli to induce CREB phosphorylation. $A$, APs were evoked at $5 \mathrm{~Hz}$ in a single presynaptic cell (arrow, blue), generating EPSPs in the surrounding postsynaptic neurons (arrowheads). After EPSP stimulation, the vast majority of postsynaptic neurons exhibited significant phospho-CREB staining, seen as red (inset) After eliminating the blue light, a lack of red phospho-CREB staining was observed in the presynaptic neuron. $B$, Field stimulation for $18 \mathrm{sec}$ at 50 $\mathrm{Hz}$ or $180 \mathrm{sec}$ at $5 \mathrm{~Hz}$ to generate EPSPs and APs resulted in significant CREB phosphorylation (left bars). Eliminating EPSPs with AP-5 $(50 \mu \mathrm{M})$ and CNQX $(10 \mu \mathrm{M})$, leaving only field-stimulated APs, eliminated the induced CREB phosphorylation (middle bars). Potentiation of L-type channels with Bay K8644 enabled APs to generate CREB phosphorylation in a high percentage of neurons (right bars).

1996). Near the presynaptic neuron (Fig. $1 A$, blue), almost all of the surrounding cells display typical clear nuclear phosphoCREB (detected with an antibody specific for pCREB and a rhodamine-conjugated secondary antibody), illustrating that EPSPs constitute a powerful and sufficient input to produce CREB phosphorylation. In contrast, the presynaptic neuron was poorly stained, if at all, by the anti-pCREB antibody (Fig. 1 $\mathrm{A}$, inset), indicating that APs alone are typically not potent stimuli to activate CREB phosphorylation. Similar results were observed in six other experiments. It should be noted that only 5-10\% of the neurons in these cultures are GABAergic, as determined by immunocytochemical staining with an anti-GAD antibody (our unpublished results).

Additional tests of the possible impact of spike activity in the absence of synaptic activity were performed using field stimulation with extracellular electrodes to excite the hippocampal neu- rons (Fig. 1B). With CNQX $(10 \mu \mathrm{M})$ and AP-5 $(50 \mu \mathrm{M})$ present, the field stimulation evoked action potentials, as verified by direct whole-cell recordings from individual pyramidal cells and optical monitoring of intracellular $\mathrm{Ca}^{2+}$ transients (Deisseroth et al., 1996). Under these conditions, only a small percentage of neuronal nuclei displayed immunostaining with the anti-pCREB antibody (middle bars), in sharp contrast to the widespread CREB phosphorylation observed when synaptic transmission was allowed (left bars) (Deisseroth et al., 1996). These results were in good agreement with the findings obtained in single-cell stimulation experiments (Fig. $1 A$ ). The ineffectiveness of spikes alone was particularly interesting in view of previous $\mathrm{Ca}^{2+}$ imaging, which showed prominent intracellular $\mathrm{Ca}^{2+}$ transients in the cultured hippocampal neurons under the same stimulation conditions (Deisseroth et al., 1996).

One hypothesis to explain the sharply contrasting effects of action potentials and EPSPs invokes a differential effect of spikes and EPSPs on a particular form of $\mathrm{Ca}^{2+}$ delivery rather than $\mathrm{Ca}^{2+}$ elevation overall. Indeed, previous work has demonstrated that L-type $\mathrm{Ca}^{2+}$ channels contribute only a fraction of the overall $\mathrm{Ca}^{2+}$ influx, yet play a disproportionately large role in inducing CREB phosphorylation (Deisseroth et al., 1998). To test for involvement of L-type channels in the spike-EPSP discrimination, we reexamined the effects of field-stimulated APs, evoked in the presence of synaptic blockade, but with further addition of the L-type agonist Bay K8644. Under these circumstances, the action potentials became much more effective in inducing CREB phosphorylation (Fig. 1B, right bars). This reinforced the view that the $\mathrm{Ca}^{2+}$ influx through L-type $\mathrm{Ca}^{2+}$ channels is critical for CREB phosphorylation. The key question that remained is whether the differential effects of synaptic activity and action potentials could be understood in terms of L-type channel properties.

\section{Divalent cation influx through L-type and other $\mathrm{Ca}^{2+}$ channels during AP- and EPSP-like depolarizations}

Based on the essential contribution of L-type $\mathrm{Ca}^{2+}$ channels, a straightforward explanation for the relative inability of APs to promote CREB phosphorylation is that they are relatively ineffective in activating L-type channels compared with EPSPs. To test this hypothesis, we compared the L-type $\mathrm{Ca}^{2+}$ channel currents generated by various waveforms in cultured CA3-CA1 hippocampal pyramidal neurons under voltage clamp with either $5 \mathrm{mM} \mathrm{Ca}^{2+}$ or $\mathrm{Ba}^{2+}$ as charge carriers $\left(\mathrm{Ba}^{2+}\right.$ was typically used to avoid complications arising from $\mathrm{Ca}^{2+}$-activated currents). The neurons were depolarized using two standard waveforms, a mock action potential consisting of a series of voltage ramps (Fig. 2A) (Wheeler et al., 1996) or a pulse to $-30 \mathrm{mV}$ (Fig. 2B), approximating the degree of depolarization achieved by EPSPs induced by trains of synaptic input to hippocampal dendrites (Magee and Johnston, 1995). A pharmacological dissection using the L-type antagonist nifedipine $(5 \mu \mathrm{M})$ allowed the contribution of L-type channels to be compared with that of other voltagedependent $\mathrm{Ca}^{2+}$ channels as a useful reference. Figure $2 A$ shows representative current traces generated by the mock AP waveform in the absence and presence of nifedipine and the nifedipine-sensitive current (difference signal). The L-type channels provided only $20 \%$ of the total $\mathrm{Ca}^{2+}$ channel current, measured at its peak (Fig. $2 A$ ) or as an integral (cumulative charge $\left.Q_{\text {AP }}\right)$. In contrast, the relative contribution of L-type channels during a pulse to $-30 \mathrm{mV}$ was approximately half of the total, measured either as peak current or the current integral (Fig. 2B). 

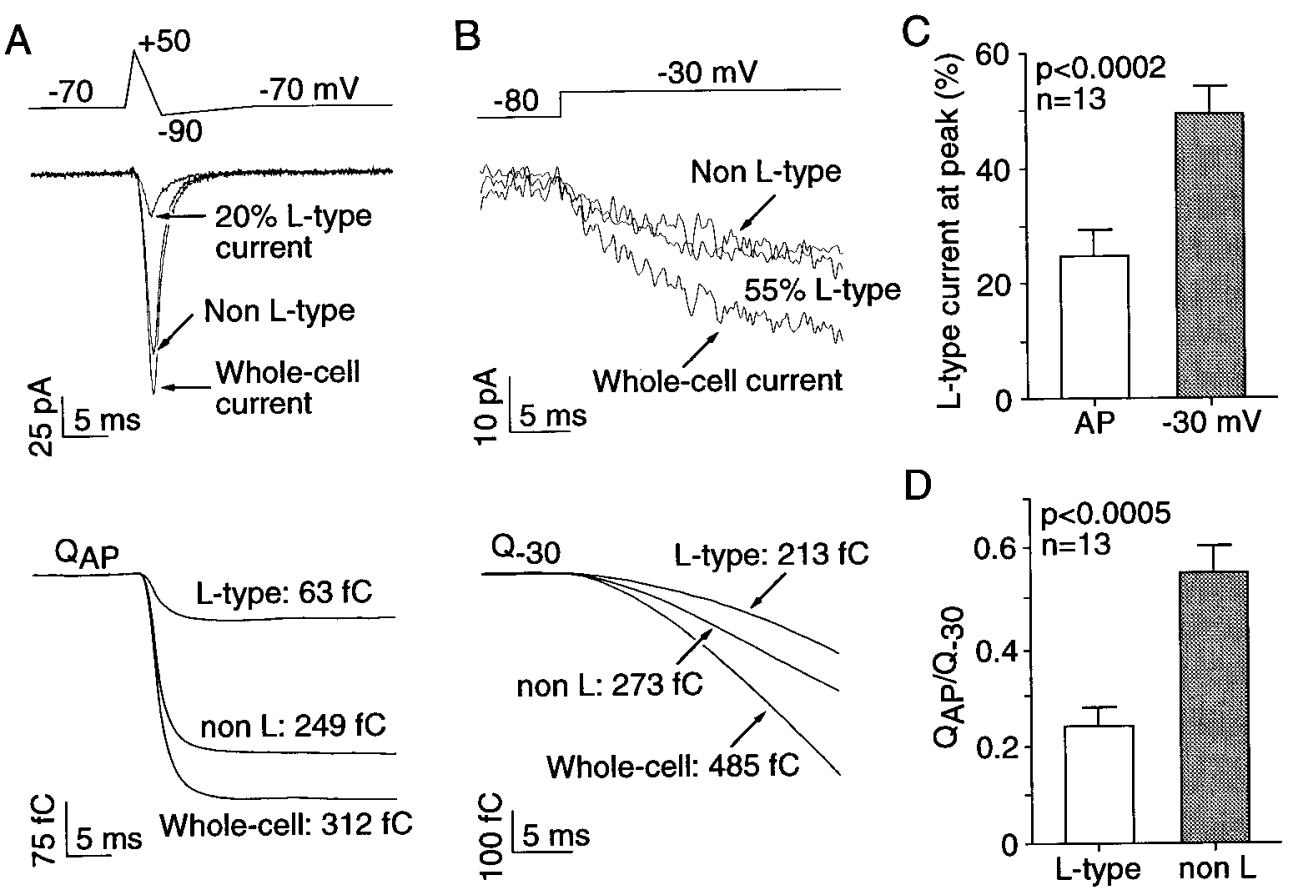

Figure 2. AP-like waveforms produced significantly less divalent cation entry through L-type $\mathrm{Ca}^{2+}$ channels than EPSP-like depolarizations. $A, \mathrm{~A}$ whole-cell patch-clamp recording of a hippocampal CA3-CA1 pyramidal neuron (5 d.i.v.). With a mock AP, the fraction of $\mathrm{Ba}^{2+}$ current attributable to L-type $\mathrm{Ca}^{2+}$ channels was $\sim 20 \%$, whether measured at its peak (top) or as cumulative charge (bottom). $B$, With a step to $-30 \mathrm{mV}$ in the same cell, the contribution of L-type $\mathrm{Ca}^{2+}$ channels was significantly greater $(\sim 50 \%)$. Compared with AP stimulation, a step to $-30 \mathrm{mV}$ increased the amount of charge entering through L-type channels by $338 \%$, whereas for non-Lchannels, the increase was only $10 \%$. $C$, With AP waveforms, $\mathrm{L}$-type $\mathrm{Ca}^{2+}$ channels made up only a small percentage of the whole-cell current $(24.8 \pm 4.6 \%$, measured at the peak). With a step to $-30 \mathrm{mV}$, the percentage is significantly greater $(49.4 \pm 4.8 \%$; $t=5.25 ; p<0.0002 ; n=13) . D$, The ratio of charge entry with an AP waveform $\left(Q_{\mathrm{AP}}\right)$ versus a step to $-30 \mathrm{mV}$ $\left(Q_{-30}\right)$, for L-type and non-L-type $\mathrm{Ca}^{2+}$ channels. $Q_{\mathrm{AP}} / Q_{-30}$ was significantly smaller for L-type $\mathrm{Ca}^{2+}$ channels $(0.24 \pm 0.04)$ than non-L-channels $(0.55 \pm 0.06 ; t=4.76 ; p<0.0005$; $n=13)$.

Similar results were obtained in pooled data from a total of 13 cells (Fig. 2C). With mock APs, L-type channels contributed $24.8 \pm 4.6 \%$ of the whole-cell $\mathrm{Ca}^{2+}$ current (mean $\pm \mathrm{SEM}$ ), significantly less than the $49.4 \pm 4.8 \%$ observed with a step to $-30 \mathrm{mV}(t=5.25 ; p<0.0002)$. Our findings with AP waveforms were in good agreement with fura- 2 measurements in spiking pyramidal neurons in hippocampal slices, which put the fractional contribution of L-type channels at $\sim 30 \%$ (Regehr and Tank, 1992; Christie et al., 1995).

Comparisons between the current integrals are relevant because the cumulative divalent cation entry is probably most closely related to activation of $\mathrm{Ca}^{2+}$-dependent cellular processes. The integrated charge contributed by L-type $\mathrm{Ca}^{2+}$ channels during mock APs was $44.2 \pm 4.0 \mathrm{fC}$ in 13 neurons, sixfold less than the charge associated with the EPSP-like depolarization to $-30 \mathrm{mV}\left(Q_{-30}\right), 244.9 \pm 53.5 \mathrm{fC}$. The corresponding values for non-L-type channels were $175.0 \pm 42.2$ and $322.7 \pm 37.7 \mathrm{fC}$, a difference of less than twofold. A slightly different representation of the same data compares the ratio of charge, calculated for individual experiments (Fig. 2D). Here again, there was a striking difference between $Q_{\mathrm{AP}} / Q_{-30}$ for L-type $\mathrm{Ca}^{2+}$ channels $(0.25 \pm$ $0.04)$ and non-L-type channels $(0.55 \pm 0.06 ; t=4.55 ; p<0.0005)$.

\section{L-type calcium channels activate at more hyperpolarized potentials than other calcium channels}

Further analysis was performed to determine what functional properties of $\mathrm{L}$-type $\mathrm{Ca}^{2+}$ channels were responsible for the discrimination between EPSP- and AP-like depolarizations. The voltage-dependence of L-type channels was considered as an obvious possibility. Figure $3, A$ and $B$, compares the activation of L-type and non-L-type channels at $-30 \mathrm{mV}$, referenced to the current activated at $0 \mathrm{mV}$. The milder depolarization produced a substantial current through L-type channels but little current through non-L-type channels relative to that seen with stronger depolarizations. This was substantiated by analysis of the ratio of L-type and non-L-type currents at various potentials (Fig. $3 C$ ). In
16 neurons, the ratio ranged from near unity at $-30 \mathrm{mV}$ to $\sim 0.4$ at $0 \mathrm{mV}$, a significant decrease $(t=3.00 ; p<0.01)$.

Ramp depolarizations provided a convenient means for characterizing the possible differences in voltage-dependence of activation of L-type and other voltage-gated calcium channels over a broader range of potentials. Figure $3 D$ shows the nifedipinesensitive and nifedipine-insensitive components of the whole-cell $\mathrm{Ba}^{2+}$ current. The inward current reached its maximum at more negative potentials for L-type channels $(-11.2 \pm 1.9 \mathrm{mV})$ than non-L-type channels $(-4.1 \pm 1.2 \mathrm{mV} ; t=4.17 ; p<0.002)$. The voltage-dependence of channel permeability was extracted by dividing the current values at each potential by an expression for an open channel current-voltage relationship, derived from the Goldman-Hodgkin-Katz equation (Hille, 1992; Bargas et al., 1994). The voltage for half-activation $\left(V_{1 / 2}\right)$ of L-type and nonL-type channels differed by $\sim 5 \mathrm{mV}$ in this example (Fig. $3 E$ ). Pooled results from 13 neurons (Fig. $3 F$ ) yielded $V_{1 / 2}$ values of $-14.2 \pm 1.6 \mathrm{mV}$ for L-type current and $-9.2 \pm 1.4 \mathrm{mV}$ for non-L-type currents $(t=3.16 ; p<0.01)$. Thus, voltagedependent opening of L-type channels occurs at significantly more negative potentials, in qualitative agreement with reports of activation characteristics in other systems (see Discussion).

\section{L-type calcium channels activate more slowly than other calcium channels}

To understand why L-type channels are relatively unresponsive to action potentials, we looked more closely at their activation kinetics. Acutely dissociated neurons were used for this analysis to optimize the speed of imposed voltage changes. Figure $4 A$ compares L-type and non-L-type currents at $-20 \mathrm{mV}$ in a typical neuron. The $10-90 \%$ rise time was more than twice as long for L-type channels as for non-L-type channels. This finding was representative of pooled results over a range of potentials (Fig. $4 B$ ). In nine neurons, the $10-90 \%$ rise time for L-type channels was between twofold and threefold longer than for non-L-type channels at all potentials between -30 and $0 \mathrm{mV}(t=2.39 ; p<$ 
Figure 3. L-Type $\mathrm{Ca}^{2+}$ channels activate at more negative potentials than other high voltage-acitvated $\mathrm{Ca}^{2+}$ channels. $A$, Considerable activation of ative to that evoked at $0 \mathrm{mV}$. $B$, In the same cell, non-L-type channels are only marginally activated at $-30 \mathrm{mV}$. C, The ratio of L-type to non-L-type current was significantly greater at more negative potentials $(F=4.72 ; p<0.01 ; n=$ 13). $D$, The non-L-type and L-type currents observed with a depolarizing ramp. The arrows mark positions of peak current along the voltage axis (voltage difference, $7.9 \mathrm{mV}$ ). $E$, Voltagedependent activation of L-type and non-L-type $\mathrm{Ca}^{2+}$ channels, represented as relative permeability, fitted with Boltzmann functions. In this typical cell, L-type $\mathrm{Ca}^{2+}$ channels activated at more negative potentials than non-L-type channels $(\Delta V, \sim 5 \mathrm{mV}) . F$, Statistical summary of the differences in halfactivation voltage of L-type channels $(-14.2 \pm 1.6 \mathrm{mV})$ and non-L-type channels $(-9.2 \pm 1.4 \mathrm{mV} ; t=3.16 ; p<0.01$; $n=13)$. L-type channels occurs at $-30 \mathrm{mV}$ rel-
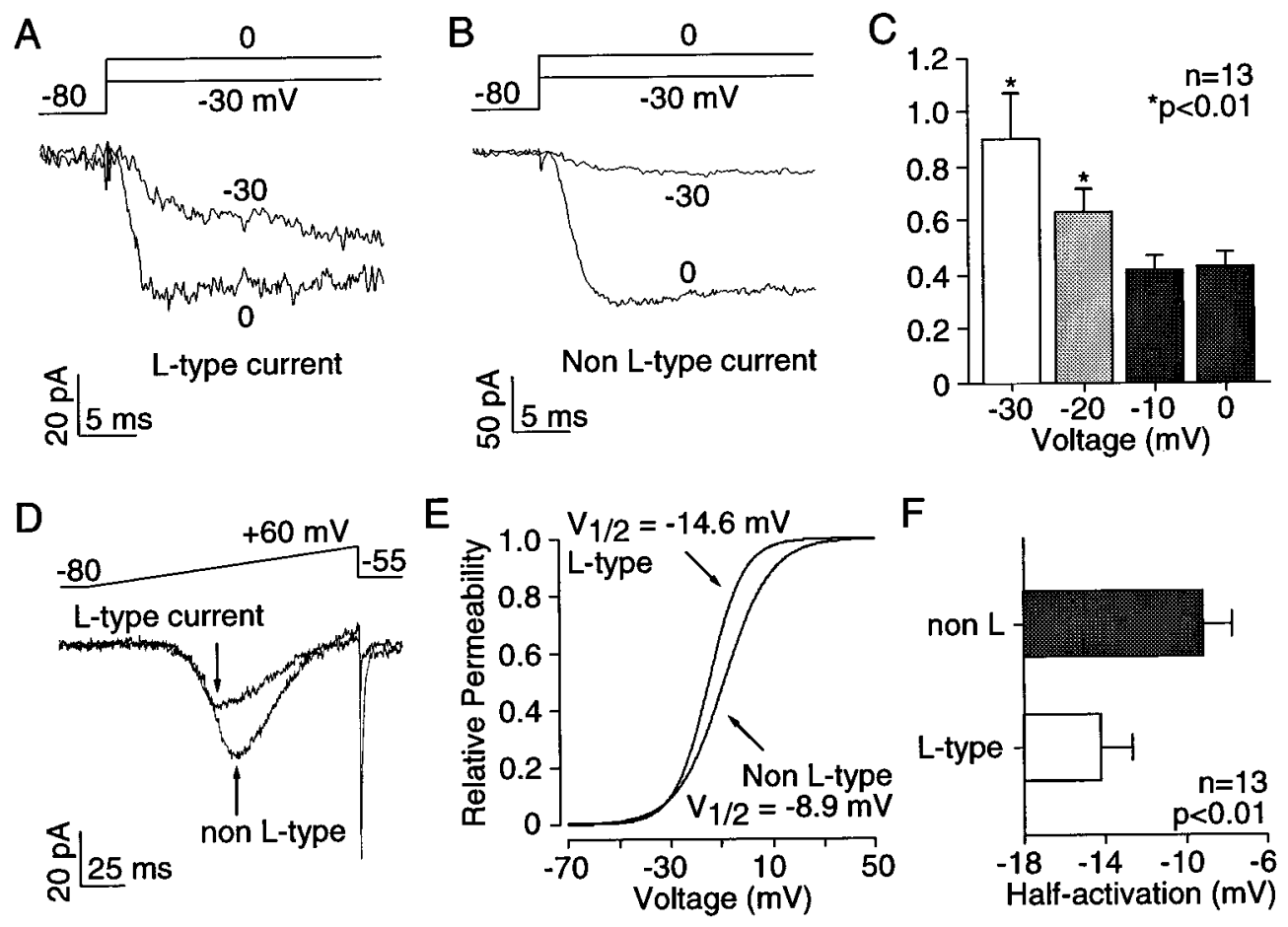

0.05). This helps explain why activation of L-type channels was relatively unresponsive to brief depolarizations such as action potentials.

\section{Enhancement of L-type $\mathrm{Ca}^{2+}$ channels will induce CREB phosphorylation after AP stimulation}

To complete the picture of how activity of L-type $\mathrm{Ca}^{2+}$ channels may act to discriminate between stimuli, we examined the effect of Bay K8644 on L-type currents. Because AP stimulation gained the ability to induce CREB phosphorylation in the presence of this L-type agonist (Fig. 1B), one might expect Bay K8644 to cause a substantial increase in cumulative divalent entry during AP stimulation. Figure $5 A$ shows $\mathrm{Ba}^{2+}$ currents in a control run and in the presence of nifedipine $(5 \mu \mathrm{M})$ or Bay K8644 $(5 \mu \mathrm{M})$. There was a large increase in the amplitude and duration of the inward current transient upon application of the agonist. The integrated currents contributed by the nifedipine-sensitive and Bay K8644-sensitive components are shown in Figure $5 B$. The $Q_{\text {AP }}$ supported by L-type channels increased by $\sim 10$-fold. Pooled results from 18 neurons subjected to the same experimental regimen are displayed in Figure $5 C$. The accumulated charge carried by L-type channels increased from $48.0 \pm 6.4 \mathrm{fC}$ in control to $447.0 \pm 48.3 \mathrm{fC}$ with application of Bay K8644 $(t=$ 8.96; $p<0.0001)$. The more than ninefold increase on average exceeds the approximate fivefold differential between $Q_{-30}$ and $Q_{\text {AP }}$ in Figure $2 D$. Thus, the electrophysiological effect of Bay K8644 is large enough to account for AP-dependent CREB phosphorylation in its presence.

\section{DISCUSSION}

The experiments in this paper addressed an apparent contradiction: spike activity alone is much less effective than synaptic activity in causing rapid $\mathrm{Ca}^{2+}$-dependent $\mathrm{CREB}$ phosphorylation, despite the fact that both forms of activity strongly raise bulk intracellular $\mathrm{Ca}^{2+}$ concentrations (Deisseroth et al., 1996). The resolution of this paradox hinges on the critical role of $\mathrm{Ca}^{2+}$ entry though L-type channels in activation of signaling to CREB (Sheng et al., 1991; Deisseroth et al., 1996). Our voltage-clamp experiments demonstrated that the biophysical properties of L-type channels in hippocampal pyramidal cells allow them to act as a kinetic filter to differentiate between different forms of
Figure 4. L-Type $\mathrm{Ca}^{2+}$ channels have significantly slower activation kinetics than other $\mathrm{Ca}^{2+}$ channels in acutely dissociated hippocampal neurons. $A$, With a step to $-20 \mathrm{mV}$, L-type channels activate more than two times slower than non-Ltype currents. $B$, At each of four different potentials, the 10-90\% rise time for L-type channels was significantly longer than that for non-L-type channels $(t \geq 2.39 ; p<0.05 ; n=9)$.
A

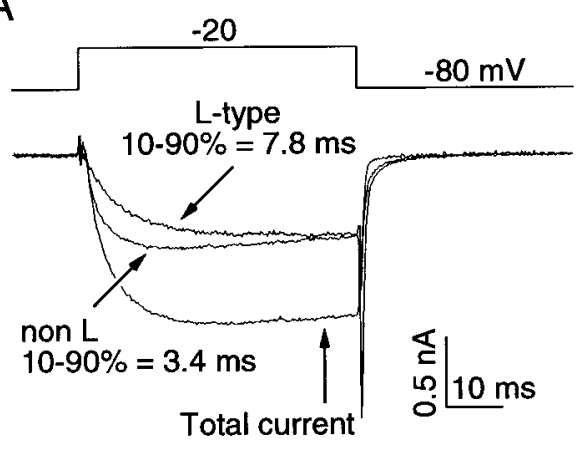

B

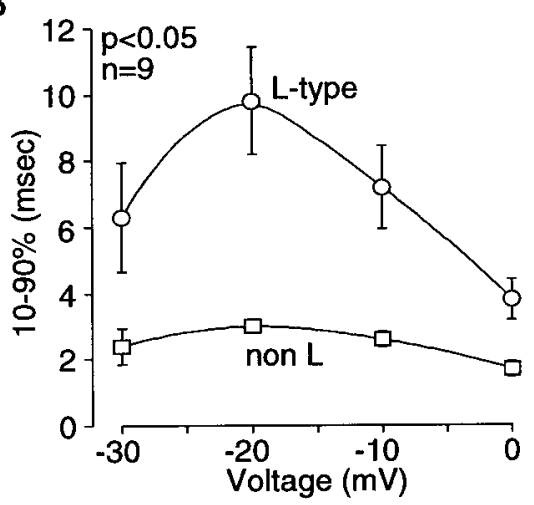


A

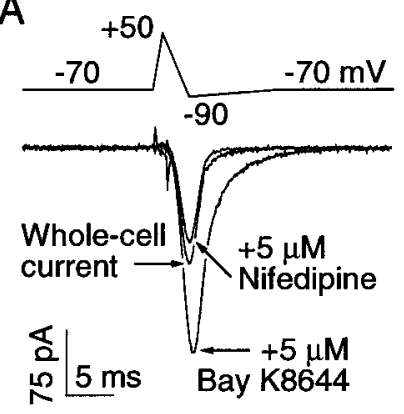

B

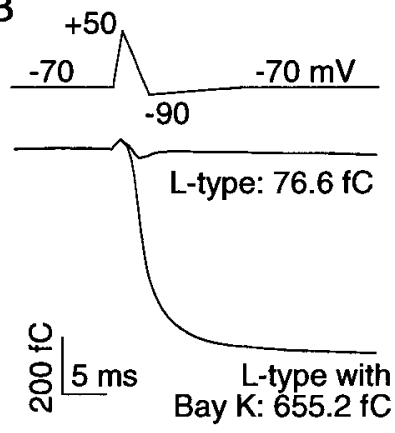

C

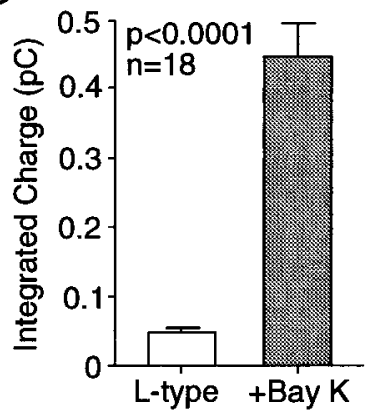

Figure 5. Increased activation of L-type $\mathrm{Ca}^{2+}$ channels with AP waveforms caused by (-)Bay K8644. A, Whole-cell current with an AP waveform under control conditions and in the presence of either nifedipine $(5 \mu \mathrm{M})$ or Bay K8644 $(5 \mu \mathrm{M}) . B$, In this cell, Bay K8644 produced an $\sim 8.5$-fold increase in the cumulative charge entry through L-type channels. $C$, Pooled results showing the effect of Bay K8644 on L-type current evoked by mock APs $(45.3 \pm 6.3$ vs $439.2 \pm 47.0$ fC; $p<0.0001 ; n=18)$. depolarizing stimuli. Depolarizations comparable with synaptically driven dendritic depolarizations were strong stimuli for divalent cation entry because of the ability of L-type $\mathrm{Ca}^{2+}$ channels to activate at relatively negative potentials. Conversely, action potentials were poor activators of divalent cation entry through L-type channels because of their relatively slow activation kinetics. The combination of voltage- and time-dependent properties of L-type channels strongly favored divalent cation entry with EPSPs as opposed to APs, thus contributing to the different effects of synaptic activity and spike activity on CREB phosphorylation. By using Bay K8644, we were able to greatly increase the flux through L-type $\mathrm{Ca}^{2+}$ channels associated with AP stimulation, to a point of exceeding that generated by EPSPlike depolarizations in the absence of agonist. Accordingly, AP stimulation in the presence of Bay K8644 was effective in causing CREB phosphorylation (Fig. 1B).

Our hypothesis for the role of L-type channels in EPSP-spike discrimination would be broadly applicable if two conditions held true in other neuronal systems: first, that L-type channels are endowed with a privileged role in signaling from cell periphery to nucleus, and second, that the biophysical properties of L-type channels are well-represented by our studies in hippocampal neurons. Previous studies have established the importance of L-type calcium channels in CREB phosphorylation and downstream gene expression in several brain regions, including neostriatum (Liu and Graybiel, 1996, 1998; Rajadhyaksha et al., 1999), cortex (Murphy et al., 1991; Shieh et al., 1998; Tao et al., 1998), olfactory bulb (Cigola et al., 1998), retina (Yoshida et al., 1995), and cerebellum (Bito et al., 1999). Furthermore, there are hints that L-type and non-L-type channels in other neuronal systems would show contrasts similar to those reported here upon examination of cumulative charge entry. Depolarizations to $-25 \mathrm{mV}$ were sufficient to cause activation of L-type channels in spiny cortical neurons in culture, as judged by fluo-3 imaging of somatic $\mathrm{Ca}^{2+}$ transients (Nakazawa and Murphy, 1999). The more negative voltage range of activation of L-type channels has been noted in neuroblastoma cells (Kasai and Neher, 1992), cerebellar granule neurons (Marchetti et al., 1995), hippocampal CA3 pyramidal cells (Avery and Johnston, 1996), and neostriatal neurons (Song and Surmeier, 1996). The slower time course of L-type channel activation can also be seen in recordings from cerebellar granule neurons (Randall and Tsien, 1995). In hippocampal neurons, differences between the biophysical properties of L-type and non-L-type channels showed no clear dependence on age, inasmuch as they were similar in acutely dissociated adult neurons and those cultured at postnatal day 1 (P1) to P2. Thus, participation of L-type channels may be of general relevance to differential responses to EPSPs and spikes. As a separate question, it remains to be determined whether L-type channels also support action potential-driven nuclear changes in sensory neurons and other cells that lack synaptic inputs (Fields et al., 1997), or in hippocampal pyramidal neurons that are spiking in response to strong antidromic stimulation with theta-burst patterns (Dudek and Fields, 1998).

The coupling of L-type channels and NMDARs to a rapid pathway for CREB phosphorylation (Ghosh et al., 1994; Deisseroth et al., 1998; Hardingham et al., 1998) is noteworthy because both $\mathrm{Ca}^{2+}$ influx pathways are preferentially activated by EPSPs as opposed to action potentials. The mechanism of such coupling has become increasingly clear. After depolarization, rapid CREB phosphorylation is triggered by calcium-dependent, CaM translocation from the cytosol into the nucleus (Deisseroth et al., 1998) (see also Pruschy et al., 1994; Luby-Phelps et al., 1995; Craske et al., 1999; Liao et al., 1999). Once in the nucleus, the CaM triggers CREB phosphorylation via CaM-dependent protein kinases (Bito et al., 1996). CaM translocation was only observed after activation of L-type channels or NMDARs but not other voltage-gated $\mathrm{Ca}^{2+}$ channels (Deisseroth et al., 1998). Although it is not critical for this paper, it will clearly be of interest to know how such selective communication comes about at the molecular level. L-Type channels often appear to be clustered with NMDARs (Hell et al., 1996), suggesting that both $\mathrm{Ca}^{2+}$ delivery systems might signal to the same pool of $\mathrm{CaM}$ in quiescent cells. The importance of local $\mathrm{Ca}^{2+}$ signaling at sites of $\mathrm{Ca}^{2+}$ entry is already known from work with $\mathrm{Ca}^{2+}$ chelators (Deisseroth et al., 1996). Further cooperation between voltageand ligand-gated channels may occur during synaptic depolarizations because of voltage-dependent gating of L-type $\mathrm{Ca}^{2+}$ channels and voltage-dependent relief of $\mathrm{Mg}^{2+}$ block of NMDARs (Graef et al., 1999; Rajadhyaksha et al., 1999).

The ability of L-type channels to selectively filter different types of stimuli is undoubtedly important not just for CREB signaling but for other signaling pathways to the nucleus as well. For example, L-type channels work through $\mathrm{CaM}$ to activate signaling pathways involving mitogen-activated protein kinaseextracellular signal-regulated kinase (Wu et al., 1998), serum response factor (Misra et al., 1994), and nuclear factor of activated T-cells (Graef et al., 1999). This in turn leads to the transcription of $c$-fos and other immediate-early genes (Murphy et al., 1991; Thompson et al., 1995), growth factors such as BDNF (Shieh et al., 1998; Tao et al., 1998), and calcium-regulatory proteins such as $\mathrm{IP}_{3} \mathrm{R} 1$ (Genazzani et al., 1999; Graef et al., 1999). Through activation of gene transcription, L-type channels also exert important effects on cell fate (Brosenitsch et al., 1998; Cigola et al., 1998), axonal and dendritic guidance (McAllister et al., 1996; Bishop and Milton, 1998; Ohbayashi et al., 1998), and 
long-term potentiation and long-term depression (Aniksztejn and Ben-Ari, 1991; Christie and Abraham, 1994; Hanse and Gustafsson, 1995; Huber et al., 1995; Bi and Poo, 1998; Izumi and Zorumski, 1998; Kapur et al., 1998; Manahan-Vaughan et al., 1998; Norris et al., 1998; Shankar et al., 1998). Given the importance of L-type channels for neuronal development and plasticity, it is particularly noteworthy that they support distinctions between different forms of physiological stimulation.

\section{REFERENCES}

Aniksztejn L, Ben-Ari Y (1991) Novel form of long-term potentiation produced by a $\mathrm{K}^{+}$channel blocker in the hippocampus. Nature 349:67-69.

Avery RB, Johnston D (1996) Multiple channel types contribute to the low-voltage-activated calcium current in hippocampal CA3 pyramidal neurons. J Neurosci 16:5567-5582.

Bargas J, Howe A, Eberwine J, Cao Y, Surmeier DJ (1994) Cellular and molecular characterization of $\mathrm{Ca}^{2+}$ currents in acutely isolated, adult rat neostriatal neurons. J Neurosci 14:6667-6686.

Bi GQ, Poo MM (1998) Synaptic modifications in cultured hippocampal neurons: dependence on spike timing, synaptic strength, and postsynaptic cell type. J Neurosci 18:10464-10472.

Bishop DL, Milton RL (1998) Nimodipine suppresses preferential reinnervation of mouse soleus muscles by slow alpha-motoneurons. Exp Neurol 154:366-370.

Bito H, Deisseroth K, Tsien RW (1996) CREB phosphorylation and dephosphorylation: a $\mathrm{Ca}^{2+}$ - and stimulus duration-dependent switch for hippocampal gene expression. Cell 87:1203-1214.

Bito H, Deisseroth K, Tsien RW (1999) Activity-dependent regulation of communication from synapse to nucleus, pp 111-123. Proceedings of the 22nd International Foundation. Taniguchi Symposium.

Brosenitsch TA, Salgado-Commissariat D, Kunze DL, Katz DM (1998) A role for L-type calcium channels in developmental regulation of transmitter phenotype in primary sensory neurons. J Neurosci 18:1047-1055.

Chalazonitis A, Zigmond RE (1980) Effects of synaptic and antidromic stimulation on tyrosine hydroxylase activity in the rat superior cervical ganglion. J Physiol (Lond) 300:525-538.

Christie BR, Abraham WC (1994) L-type voltage-sensitive calcium channel antagonists block heterosynaptic long-term depression in the dentate gyrus of anaesthetized rats. Neurosci Lett 167:41-45.

Christie BR, Eliot LS, Ito K, Miyakawa H, Johnston D (1995) Different $\mathrm{Ca}^{2+}$ channels in soma and dendrites of hippocampal pyramidal neurons mediate spike-induced $\mathrm{Ca}^{2+}$ influx. J Neurophysiol 73:2553-2557.

Cigola E, Volpe BT, Lee JW, Franzen L, Baker H (1998) Tyrosine hydroxylase expression in primary cultures of olfactory bulb: role of L-type calcium channels. J Neurosci 18:7638-7649.

Craske M, Takeo T, Gerasimenko O, Vaillant C, Torok K, Petersen $\mathrm{OH}$, Tepikin AV (1999) Hormone-induced secretory and nuclear translocation of calmodulin: oscillations of calmodulin concentration with the nucleus as an integrator. Proc Natl Acad Sci USA 96:4426-4431.

Deisseroth K, Bito H, Tsien RW (1996) Signaling from synapse to nucleus: postsynaptic CREB phosphorylation during multiple forms of hippocampal synaptic plasticity. Neuron 16:89-101.

Deisseroth K, Heist EK, Tsien RW (1998) Translocation of calmodulin to the nucleus supports CREB phosphorylation in hippocampal neurons. Nature 392:198-202.

Dudek SM, Fields RD (1998) Somatic action potentials are sufficient for rescue of tagged synapses. Soc Neurosci Abstr 28:426.

Fields RD, Eshete F, Stevens B, Itoh K (1997) Action potentialdependent regulation of gene expression: temporal specificity in $\mathrm{Ca}^{2+}$, cAMP-responsive element binding proteins, and mitogen-activated protein kinase signaling. J Neurosci 17:7252-7266.

Genazzani AA, Carafoli E, Guerini D (1999) Calcineurin controls inositol 1,4,5-trisphosphate type 1 receptor expression in neurons. Proc Natl Acad Sci USA 96:5797-5801.

Ghosh A, Ginty DD, Bading H, Greenberg ME (1994) Calcium regulation of gene expression in neuronal cells. J Neurobiol 25:294-303.

Ginty DD, Kornhauser JM, Thompson MA, Bading H, Mayo KE, Takahashi JS, Greenberg ME (1993) Regulation of CREB phosphorylation in the suprachiasmatic nucleus by light and a circadian clock. Science 260:238-241.
Graef IA, Mermelstein PG, Stankunas K, Neilson JR, Deisseroth K, Tsien RW, Crabtree GR (1999) L-type calcium channels and GSK-3 regulate NF-ATc4 activity in hippocampal neurons. Nature 401:703-708.

Hamill OP, Marty A, Neher E, Sakmann B, Sigworth FJ (1981) Improved patch-clamp techniques for high-resolution current recording from cells and cell-free membrane patches. Pflügers Arch 391:85-100.

Hanse E, Gustafsson B (1995) Long-term potentiation in the hippocampal CA1 region in the presence of $N$-methyl-D-aspartate receptor antagonists. Neuroscience 67:531-539.

Hardingham GE, Cruzalegui FH, Chawla S, Bading H (1998) Mechanisms controlling gene expression by nuclear calcium signals. Cell Calcium 23:131-134.

Hell JW, Westenbroek RE, Breeze LJ, Wang KK, Chavkin C, Catterall WA (1996) $N$-methyl-D-aspartate receptor-induced proteolytic conversion of postsynaptic class C L-type calcium channels in hippocampal neurons. Proc Natl Acad Sci USA 93:3362-3367.

Hille B (1992) Ionic channels of excitable membranes. Sunderland, MA: Sinauer.

Huber KM, Mauk MD, Kelly PT (1995) Distinct LTP induction mechanisms: contribution of NMDA receptors and voltage-dependent calcium channels. J Neurophysiol 73:270-279.

Impey S, Obrietan K, Wong ST, Poser S, Yano S, Wayman G, Deloulme JC, Chan G, Storm DR (1998) Cross talk between ERK and PKA is required for $\mathrm{Ca} 2+$ stimulation of CREB- dependent transcription and ERK nuclear translocation. Neuron 21:869-883.

Izumi Y, Zorumski CF (1998) LTP in CA1 of the adult rat hippocampus and voltage-activated calcium channels. NeuroReport 9:3689-3691.

Kandel ER, Klein M, Castellucci VF, Schacher S, Goelet P (1986) Some principles emerging from the study of short- and long-term memory. Neurosci Res 3:498-520.

Kapur A, Yeckel MF, Gray R, Johnston D (1998) L-Type calcium channels are required for one form of hippocampal mossy fiber LTP. J Neurophysiol 79:2181-2190.

Kasai H, Neher E (1992) Dihydropyridine-sensitive and omegaconotoxin-sensitive calcium channels in a mammalian neuroblastomaglioma cell line. J Physiol (Lond) 448:161-188.

Liao B, Paschal BM, Luby-Phelps K (1999) Mechanism of $\mathrm{Ca}^{2+}$ dependent nuclear accumulation of calmodulin. Proc Natl Acad Sci USA 96:6217-6222.

Liu FC, Graybiel AM (1996) Spatiotemporal dynamics of CREB phosphorylation: transient versus sustained phosphorylation in the developing striatum. Neuron 17:1133-1144.

Liu FC, Graybiel AM (1998) Region-dependent dynamics of cAMP response element-binding protein phosphorylation in the basal ganglia. Proc Natl Acad Sci USA 95:4708-4713.

Luby-Phelps K, Hori M, Phelps JM, Won D (1995) $\mathrm{Ca}^{2+}$-regulated dynamic compartmentalization of calmodulin in living smooth muscle cells. J Biol Chem 270:21532-21538.

Luckman SM, Dyball RE, Leng G (1994) Induction of c-fos expression in hypothalamic magnocellular neurons requires synaptic activation and not simply increased spike activity. J Neurosci 14:4825-4830.

Magee JC, Johnston D (1995) Synaptic activation of voltage-gated channels in the dendrites of hippocampal pyramidal neurons. Science 268:301-304.

Malgaroli A, Tsien RW (1992) Glutamate-induced long-term potentiation of the frequency of miniature synaptic currents in cultured hippocampal neurons. Nature 357:134-139.

Manahan-Vaughan D, Braunewell KH, Reymann KG (1998) Subtypespecific involvement of metabotropic glutamate receptors in two forms of long-term potentiation in the dentate gyrus of freely moving rats. Neuroscience 86:709-721.

Marchetti C, Amico C, Usai C (1995) Functional characterization of the effect of nimodipine on the calcium current in rat cerebellar granule cells. J Neurophysiol 73:1169-1180.

McAllister AK, Katz LC, Lo DC (1996) Neurotrophin regulation of cortical dendritic growth requires activity. Neuron 17:1057-1064.

Mermelstein PG, Becker JB, Surmeier DJ (1996) Estradiol reduces calcium currents in rat neostriatal neurons via a membrane receptor. J Neurosci 16:595-604.

Misra RP, Bonni A, Miranti CK, Rivera VM, Sheng M, Greenberg ME (1994) L-Type voltage-sensitive calcium channel activation stimulates 
gene expression by a serum response factor-dependent pathway. J Biol Chem 269:25483-25493.

Murphy TH, Worley PF, Baraban JM (1991) L-Type voltage-sensitive calcium channels mediate synaptic activation of immediate early genes. Neuron 7:625-635.

Nakazawa H, Murphy TH (1999) Activation of nuclear calcium dynamics by synaptic stimulation in cultured cortical neurons. J Neurochem 73:1075-1083.

Norris CM, Halpain S, Foster TC (1998) Reversal of age-related alterations in synaptic plasticity by blockade of L-type $\mathrm{Ca}^{2+}$ channels. J Neurosci 18:3171-3179.

Ohbayashi K, Fukura H, Inoue HK, Komiya Y, Igarashi M (1998) Stimulation of L-type $\mathrm{Ca}^{2+}$ channel in growth cones activates two independent signaling pathways. J Neurosci Res 51:682-696.

Pruschy M, Ju Y, Spitz L, Carafoli E, Goldfarb DS (1994) Facilitated nuclear transport of calmodulin in tissue culture cells. J Cell Biol 127:1527-1536.

Rajadhyaksha A, Barczak A, Macías W, Leveque JC, Lewis SE, Konradi $\mathrm{C}$ (1999) L-Type $\mathrm{Ca}^{2+}$ channels are essential for glutamate-mediated CREB phosphorylation and $c$-fos gene expression in striatal neurons. J Neurosci 19:6348-6359.

Randall A, Tsien RW (1995) Pharmacological dissection of multiple types of $\mathrm{Ca}^{2+}$ channel currents in rat cerebellar granule neurons. J Neurosci 15:2995-3012.

Regehr WG, Tank DW (1992) Calcium concentration dynamics produced by synaptic activation of CA1 hippocampal pyramidal cells. J Neurosci 12:4202-4223.
Shankar S, Teyler TJ, Robbins N (1998) Aging differentially alters forms of long-term potentiation in rat hippocampal area CA1. J Neurophysiol 79:334-341.

Sheng M, Thompson MA, Greenberg ME (1991) CREB: a $\mathrm{Ca}^{2+}$ regulated transcription factor phosphorylated by calmodulindependent kinases. Science 252:1427-1430.

Shieh PB, Hu SC, Bobb K, Timmusk T, Ghosh A (1998) Identification of a signaling pathway involved in calcium regulation of BDNF expression. Neuron 20:727-740.

Song WJ, Surmeier DJ (1996) Voltage-dependent facilitation of calcium channels in rat neostriatal neurons. J Neurophysiol 76:2290-2306.

Tao X, Finkbeiner S, Arnold DB, Shaywitz AJ, Greenberg ME (1998) $\mathrm{Ca}^{2+}$ influx regulates BDNF transcription by a CREB family transcription factor-dependent mechanism. Neuron [Erratum 20:1297] 20:709-726.

Thompson MA, Ginty DD, Bonni A, Greenberg ME (1995) L-Type voltage-sensitive $\mathrm{Ca}^{2+}$ channel activation regulates c-fos transcription at multiple levels. J Biol Chem 270:4224-4235.

Wheeler DB, Randall A, Tsien RW (1996) Changes in action potential duration alter reliance of excitatory synaptic transmission on multiple types of $\mathrm{Ca}^{2+}$ channels in rat hippocampus. J Neurosci 16:2226-2237.

Wu G-Y, Deisseroth K, Tsien RW (1998) Spatiotemporal pattern of MAP kinase activation in hippocampal dendrites. Soc Neurosci Abstr 28:343.

Yoshida K, Imaki J, Matsuda H, Hagiwara M (1995) Light-induced CREB phosphorylation and gene expression in rat retinal cells. J Neurochem 65:1499-1504. 